\title{
Join COR@NLINE: Student Experiences in and Perceptions of Online Sessions during COVID-19 Outbreak
}

\author{
Ayşegül Takkaç Tulgar ${ }^{1}$
}

\begin{abstract}
With the advent of technology and educational devices, online courses have been increasingly utilized in education. At present, educational institutions use a variety of technological tools and applications to carry out courses at all levels. There has been a debate on the use of technology in education from such perspectives as learner success, satisfaction and interaction. Language education has also been investigated from dimensions including integration of technology in language teaching and learning processes. Within an aim to identify learner experiences in online language sessions, this intrinsic case study examined the experiences and perceptions of 23 undergraduate students following online courses at English Language Teaching Department EFL at a Turkish state university. Data were collected through the instructor's unstructured online observation notes, students' unstructured notes and their answers to open-ended questions. The results of conventional content analysis pointed at the educational, pedagogical and affective contributions of online sessions as well as covering connection problems and interactional confusion as the drawbacks in the process. In the light of the results, several suggestions are made.
\end{abstract}

Keywords: Language Education; Distance Education; Online Courses; Student Perceptions

Geliş Tarihi: 18.06.2020 - Kabul Tarihi: 02.12.2020 - Yayın Tarihi: 25.12.2020

DOI: $10.29329 /$ mjer.2020.322.17

\section{KOR@NLINE’a Katıl: Kovid-19 Dönemi Çevrimiçi Ders Anlatımlarında Öğrenci Deneyimleri ve Algıları}

Özet: Teknoloji ve eğitim araçlarının gelişmesiyle, çevrimiçi dersler eğitim alanında artan bir şekilde kullanılmaktadır. Günümüzde eğitim kurumları her düzeyde dersler yürütmek için bir dizi teknolojik araçlar ve uygulamalar kullanmaktadır. Eğitimde teknoloji kullanımı öğrenci başarısı, memnuniyeti ve katılımı gibi açılardan tartı̧̧ılmıştır. Dil eğitimi de öğrenme ve öğretme süreçlerinde teknoloji kullanımı boyutlarıyla araştırılmıştır. Çevrimiçi dil derslerinde öğrenci deneyimlerini belirlemeyi amaçlayan bu gerçek durum çalışması, Kovid-19 pandemi döneminde Türkiye'de bir devlet üniversitesinin İngilizce Öğretmenliği Anabilim Dalında çevrimiçi derslere katılan 23 lisans öğrencisinin deneyimlerini ve algılarını incelemiştir. Çalışmanın verileri öğretim elemanının yapılandırılmamış çevrimiçi gözlem notları, öğrencilerin yapılandırılmamış notları ve açık uçlu sorulara verdikleri yanıtlar yoluyla toplanmıştır. Geleneksel içerik analizinin sonuçları süreçte

\footnotetext{
${ }^{1}$ Ayşegül Takkaç Tulgar, Assist. Prof. Dr., Dept. of English Language Teaching, Atatürk University, ORCID: 0000-00016401-969X
}

Email: aysegultakkac@ hotmail.com 
gözlenen bağlantı sorunları ve etkileşim karmaşası yanında eğitimsel, pedagojik ve duyuşsal katkılara da dikkat çekmiştir. Bu sonuçlar ışığında bazı önerilerde bulunulmuştur.

Anahtar Kelimeler: Dil Eğitimi; Uzaktan Eğitim; Çevrimiçi Dersler; Öğrenci Algıları

\section{INTRODUCTION}

Along with the innovations and advances in computer and internet technologies, teaching and learning practices have moved beyond the walls of physical classroom settings. Online courses which have been observed to receive exponential interest, particularly in the last decade, have become an alternative platform to face-to-face classes (Harmon \& Tomolonis, 2019; Xu \& Jaggars, 2013). Therefore, the effectiveness of online classes has become a topic of investigation in different fields. While some research centered on the effects of learner-to-learner interactions in online courses (Kuruçay \& Inan, 2017; Moore, 2014) and the effects of online courses on learner success and satisfaction (Palmer, Holt, \& Bray, 2008; Zhang, 2016), some others revealed a comparison of online classes with face-to-face classes in terms of effectiveness (Fischer, $\mathrm{Zu}$, Rodriguez, Denaro, \& Warschauer, 2020; Xu \& Jaggars, 2013; Zhan, Xu, \& Ye, 2011).

Though studies on online classes aimed to offer a different perspective, what was common among all was that they were all conducted in periods in which face-to-face education was also possible since there were no survival cases restricting the educational practices of people around the world. Yet, at present, all the world nations have been dreadfully experiencing a severe case in which distance education became a must, not a preference. The consideration of the particular case of the pandemic caused by Covid-19 unfortunately points at the wide-spread deadly-effects influencing not only healthcare but also the field of education from K12 to higher education. Thus, the examination of the experiences of members of education, i.e. teachers and students, in this delicate and coercive period holds great significance. Carried out in this mentally-tiring and educationally demanding process, this intrinsic case study was intended to examine the experiences and perceptions of ELT students joining an online course held during the Corona period.

\section{Literature on Online Courses}

The examination of online courses from different angles has become an area receiving mounting attention in the last two decades. An increasing number of studies have been conducted in different educational contexts centering on issues ranging from the effects of different variables on online courses to the effectiveness of such courses.

Centering on the effects of gender and location variables, Nistor (2013) conducted a correlational study at a German university with 156 students studying at Psychology and Educational Sciences Departments. The results of the questionnaire indicated that while male participants had more 
stable attitudes towards the course, female participants showed more stable course participation. In addition, location was found to be a factor affecting regular participation. Taking students' perceived online presence into account, Yang, Quadir, Chen, and Miao (2016) conducted an empirical study at a Taiwanese university with students taking Digital Learning course. The results of the regression analysis showed that online presence and cognitive presence were significant factors affecting learning performance. At a state university in the USA, Zhang (2016) examined the effects of the course behaviors of 88 students taking information technology online classes. The analysis of the participants' site logs and their final grades demonstrated that irregular site logs negatively affected the final grades while regular participation in board posts increased final grades. The effect of class size on online courses was also among the points examined. Bettinger, Doss, Loeb, Rogers, and Taylor (2017), on an experimental basis, examined the effects of class size in online classes held in a college in the USA. The researchers concluded that class size was not a factor having significant impact on the effectiveness of online classes.

The effects of online courses were also among the points examined with an aim to investigate the effects of an online problem-based learning approach on learners' critical thinking skills and content knowledge. Sendağ and Odabası (2009) conducted an experimental study with undergraduate students taking Computer II course at a Turkish state university. The analysis of the data collected through a test assessing content knowledge and a test assessing critical thinking skills showed that while the online practice did not have statistically significant effects on content knowledge, it significantly affected the participants' critical thinking skills. Considering the long term effects of online classes, Bosshardt and Chiang (2018) carried out an experimental study with 421 students enrolled in economics courses at an American university. The results revealed that the participants taking online course had lower performances in subsequent economics courses.

The interactional patterns in online courses are another area examined by researchers. Moore (2014) studied the effects of instructor-to-student/student-to-student interaction and instructor presence on learner success, withdrawal and satisfaction. Collecting data from 402 undergraduate students taking Public Relations Courses at an American university in relation to their success rates, withdrawal rates and course evaluations over two years, the researcher concluded that student-tostudent interactions and self-discipline were the main predictors of learner satisfaction and success in online courses. Focusing on the adoption of interactive functions in online courses, Wei, Peng, and Chou (2015) investigated the impact of interactive functions on the learning performance of 381 undergraduate students taking a general education course offered in an asynchronous online version. The results obtained through a questionnaire showed that the participants' perceptions and actual use of interactive functions directly influenced their learning performance in the online course. In a quasiexperimental research, Kuruçay and Inan (2017) studied the effects of learner-to-learner interaction on the satisfaction and learning levels of 77 undergraduate students majoring in the fields of education, 
engineering, psychology and business at an American state university. The results indicated that learner-to-learner interaction was a factor significantly contributing to learner achievement. In addition, the participants participating in online sessions were observed to develop positive perceptions towards online classes.

Literature also presents a focus on the comparison of online versus face-to-face courses, and synchronic versus asynchronic courses. Analyzing data from a state-wide system comprising of 34 technical and community colleges in the USA, Xu and Jaggars (2013) compared the effectiveness of online versus face-to-face courses in terms of learner performance. The analysis revealed that learner performance was lower in online classes compared to face-to-face classes as regards course persistence and grade. A recent comparison of online versus face-to-face courses in a USA context was conducted by Fischer, et al. (2020). The analysis of the data obtained from the course enrollments of more than twenty thousand students in 433 courses pointed at gender, previous enrollment to online courses and admission scores as main factors affecting students' preference of online or face-to-face courses. As for student success, grades in online courses were reported to be lower than those in faceto-face courses. Examining the effects of such learner variables as gender, GPA, age and commuting distance possibly affecting student performances in online and offline courses, Huh, Jin, Lee, and Yoo (2009) conducted univariate and regression analyses of the demographic and academic data from 91 undergraduate students taking accounting courses at a state university in the USA. The results indicated that there was not a statistically significant difference between online and offline classes in terms of learner performance though gender and GPA were the chief factors affecting offline courses. In Australian context, Duncan, Kenworthy, and McNamara (2012) analyzed how the quality and quantity of participation of 272 students taking accounting courses affected their course performance and final grades in synchronous and asynchronous courses. The results showed that the quality of participation increased final grades and the quantity of participation increased overall performance in the synchronous course more than the asynchronous course.

There are, though limited in number, some studies on online language courses. One of the examples of online language courses belongs to Abuseileek (2009), who conducted an online class with 79 ELT undergraduates at a university in Saudi Arabia. Collecting data through pre- and posttest, the researcher focused on the effects of method; i.e. computer-based/online vs. non-computerbased instruction, and technique, i.e. inductive vs. deductive instruction, on learning grammar. The results indicated that online sessions helped the participants better learn more complex grammatical structures compared to the non-computer based instruction. Examining the effects of learner characteristics on an online English course, Ozawa (2019) worked with 130 EFL students at a Japanese university. The data were obtained via a scale assessing attitudes towards computer assisted language learning and a scale assessing learners' previous out-of-class learning experiences. The analysis indicated that most of the participants were not comfortable with using technology in 
language education. In addition, the time spent for language development and the stated positive attitudes of the participants regarding the effectiveness of computer assisted language learning did not predict their English development through technology.

The perusal of the literature on online classes points at the growing interest capturing the imagination of researchers as regards conducting online classes in different branches of education. The overall analysis of the relevant research attracts attention to some common points and gaps in the literature. The first point is that literature presents research on online classes in such various fields as engineering (Kuruçay \& Inan, 2017), public relations (Moore, 2014), criminal justice (Dobbs, WaidLindberg, \& Carmen, 2017), economics and accounting (Bosshardt \& Chiang, 2018; Huh, et al., 2009) and computer education and information technology (Sendag \& Odabas1, 2009; Zhang, 2016). However, although online courses have been a focus in various disciplines, there are not many studies in the specific field of language education. The second point is that almost all the studies on online classes adopted quantitative research designs, pointing at the need for qualitative studies which are to offer in-depth analysis. The third point is that though online classes have received increasing attention worldwide, not many studies were conducted in Turkish context. The fourth point is that all the studies on online classes in the literature were conducted at times when face-to-face classes were also available in educational institutions. In other words, online courses were preferences instead of being mandatory practices. Therefore, setting out from these assumptions in relation to the scope, context and the circumstances of research on online courses, this intrinsic case study, carried out in Turkey, investigated the experiences and perceptions of ELT undergraduate students participating in an online course held during Covid-19 pandemic.

\section{Theoretical Framework}

The theoretical basis of this study was grounded on Community of Inquiry (Garrison, 2007; Garrison, Anderson, \& Archer, 2000, 2001) and Sociocultural Theory (Vygotsky, 1978). The main theoretical basis was Community of Inquiry $(\mathrm{CoI})$, which suggests that classes present a learning community comprising of social presence, cognitive presence and teaching presence (Garrison \& Arbaugh, 2007). Garrison (2009) defines social presence as the ability of the members to identify themselves with the learning community and develop relationships with other members by being active participants in the environment. The evaluation of online classes from this social presence perspective indicates that students taking part in online courses are offered chances to contribute to the process and be active members of the online social community. The cognitive presence is considered as the process of constructing and validating meaning with the help of the interactions available in the learning community (Garrison, et al., 2001). Continuous discussions and reasoning sessions in online classes are expected to promote students' cognitive development through proactive engagement. The last component of CoI, teaching presence, is about teachers' ability to design classes aiming to develop students' cognitive and social presence (Garrison, et al., 2001). Though having virtual nature, 
online classes also require effective course plan and design for effective instruction and learner development. Within this CoI perspective, online classes become virtual educational settings covering all the three dimensions.

This study was also grounded on Sociocultural Theory proposed by Vygotsky (1978). Within this theory, any type of learning is basically considered as a process of social interaction. The continuous and meaningful interactions among the members of the learning process, i.e. teachers and students, are the stimulators of successful learning. Taking online classes into account, one can conclude that teacher-to-student and student-to-student interactions available during online sessions help students develop their knowledge and competencies. In the particular case of language education, developing their language skills as well as learning related subject-matter knowledge is essential for the participants in this study. It can be assumed that the weekly-held online sessions enabled the participants to maintain their motivation and interest in language development through active participation which also created an atmosphere of social sharing.

\section{METHODOLOGY}

This study adopted intrinsic case study as its research design. As suggested by Stake (1995), this design enables researchers with genuine interest in particular cases to examine the case in detail. For a better understanding, detailed information about the participants and the case examined in this study is provided below.

\section{Participants}

The participants of this study were 23 junior students taking Teaching English to Young Learners II (TEYL II) course in the spring term of the 2019-2020 academic year, at a state university in Turkey. During the regular term, 54 students registered in the course but 23 of them regularly participated in online sessions. Therefore, data were collected from these regularly-participating students.

\section{The case}

Step 1-Face-to-face classes: At the beginning of the spring term, TEYL II course started as a face-to-face course with 54 students. In order to have more effective classes, the students took the course divided into two groups (A and B) receiving four hours of TEYL II classes each week. The instructor who was also the researcher (referred as instructor hereafter) designed the course to integrate articles related to TEYL as well as micro-teachings to be performed by students. The students were expected to read the week's content, participate in-class discussions about the theoretical and practical aspects of TEYL in relation to the article, write an article report reflecting their personal comments and prepare and perform micro-teaching practices. While face-to-face classes were conducted according to the plan for the first four weeks, Higher Education Council (HEC) in Turkey announced the decision to cease face-to-face classes at universities because of the Corona 
pandemic. The first announcement reported a three-week break but because of the fast-spreading effects of the virus the period was extended over the whole spring term. There was a week-break to educational practices following the decision.

Step 2-Online sessions: After the cessation of face-to-face education at tertiary level, HEC informed that universities would conduct under/graduate courses mainly through the Course Management System (CMS) infrastructures available at universities. Upon this decision, universities announced their faculty to upload their course content and materials to CMS and follow homework or project practices through the system, which would be used mainly for evaluation. The demand for the adoption of CMS meant that in undergraduate courses would be conducted asynchronously. However, as TEYL II course design was significantly based on classroom discussions on articles, the instructor decided to conduct synchronous sessions beside asynchronous ones. For this purpose, the instructor searched for different programs and applications enabling online sessions. As a result, ZOOM, a video-conferencing program, was adopted in order to conduct synchronous discussions with students for the rest of the spring term.

Upon a second announcement which was made five weeks later than the first one, the authorities at the university required the start of synchronous sessions in addition to asynchronous ones. Thus, all the courses at the ELT Department were started to be offered in both versions after the tenth week in the term. However, until this announcement, TEYL II course was conducted through synchronous sessions besides asynchronous sessions, which enabled third-graders to participate in the single online version offered among their other courses during a five-week process.

In this process, the instructor used the CMS to upload course materials and homework delivery and the application to continue online discussions. Each week, the instructor uploaded the week's article to CMS on Mondays, conducted online discussion sessions on Thursdays through ZOOM and assigned the submission of article reports on the Mondays in the following week. The students were sent a participation link through SMS supported by CMS and they were expected to log-on in the application through their mobile-phones or computers. For the safety issues, the students were asked to use the links only themselves. In addition, the waiting room system in the program was used so that the instructor gave acceptance to the participation of each student as the host. And, after each session, the instructor uploaded the video to the CMS so that those students who could not participate in the synchronous session could watch the video and follow the discussion and the participating students could re-consider discussion points by watching the record.

Step 3-Data collection: Before the main data collection process, the researcher told all the students that she was planning to conduct an academic study out of the online sessions. She informed them all about their rights and responsibilities and obtained their consent. In the main research process, the data were collected through the instructor's unstructured online observation notes 
regarding student participation and performance, the students' unstructured notes of online sessions and their answers to the open-ended questions.

The first data collection tool was the instructor's unstructured online observation notes about the students' participation and performances in online sessions (five in total). The observation notes were started to be taken after two online sessions were done after gaining familiarity to online teaching atmosphere in the two-week period. Since the instructor also conducted face-to-face classes with those students in the first four weeks of the term, she had the chance to compare learner performances in two learning contexts.

The second tool was students' unstructured notes taken after online sessions. The instructor asked the students to take notes about the online lessons after they completed the first online session because she wanted the students to form basic evaluations of the new practice (four in total). The students were told to take the notes after the sessions to reflect their fresh experiences. The notes were informal in format and there were no word limitations. The notes taken by the students who regularly participated in each session were considered for evaluation.

The third tool was the participants' answers to the open-ended questions. The questions were prepared by the instructor and two field experts were consulted for clarity and understandability of the questions. The questions were posed to the participants in the tenth week of the regular term which was the fifth week of the distance education. The reason for collecting the open-ended questions after five weeks of online courses was that after then the other courses were also offered online. Since the aim was to examine the students' evaluations of the only course offered synchronously, the questions were posed to the participants after five weeks of online sessions were conducted. Uploaded to and received through the CMS, the questions were in English and the participants were asked to provide answers in English. The open-ended questions were as follows:

1. How do you evaluate your overall experiences in the online sessions?

2. What are the advantages of participating in online sessions?

3. What are the disadvantages of participating in online sessions?

The reason for adopting these data collection instruments was to increase validity through data triangulation. With the help of these instruments, the researcher could evaluate the students' experiences in and perceptions of online sessions.

Step 4-Data analysis: The data were analyzed through conventional content analysis (Hsieh \& Shannon, 2005). Before conducting the whole analysis, the researcher shared the data and a preliminary analysis with the participants to get their approval. In the main analysis process, a threestep procedure was followed by the researcher in which all the data sets were first analyzed through individual analysis, second through within-group analysis and third among-group analysis. 
In the first step, the researcher conducted an individual analysis in which she separately went over all the data sets in order to get overall ideas about the content of the data. For this purpose, she read each data set several times and identified primary items repeated in all data sets. In the second step, a within-group analysis was followed in which each data set was evaluated in itself. In this step, the researcher conducted a comparison of the data available within each data set. In this process, recurring items were identified as codes available in each set. In the final step, an among-group analysis was conducted in which all the data sets were compared among each other. The data in one set were compared with other sets in order to identify similar and different aspects. After completing these three steps, the researcher combined the relevant codes into related categories which were also combined into broader themes.

This three-step analysis was performed in order to increase validity of analysis. A field expert was also asked to conduct the analysis following the same steps and this inter-rater analysis resulted in $80,5 \%$ exact coding, $13 \%$ similar coding and $6,5 \%$ different coding, increasing the validity of data analysis.

\section{RESULTS}

The analysis of the data pointed at two major themes: The contributions of online sessions involving educational, pedagogical and affective contributions and The drawbacks of online sessions including connection and interaction problems. This section first presents the Contributions Theme and then the Drawbacks Theme accompanied with participant comments. As there were three data sets, participant comments reflecting the common considerations are provided with abbreviations: $\mathrm{ON}$ : Instructor's unstructured online observation notes; SX-N: Student X's unstructured note and SX-OE: Student X's answer to open-ended questions.

\section{The Contributions of Online Sessions}

The online sessions were mainly appreciated because of their educational, pedagogical and affective contributions. The below table presents the first theme, its categories and related codes.

Table 1

\begin{tabular}{ll}
\hline Theme 1: The contributions of online sessions & \\
Category 1: Educational contributions & $\begin{array}{l}\text { Developing communicative skills } \\
\text { Developing field-specific knowledge }\end{array}$ \\
Category 2: Pedagogical contributions & $\begin{array}{l}\text { Course delivery } \\
\text { Virtual practice }\end{array}$ \\
Category 3: Affective contributions & $\begin{array}{l}\text { Overcoming sense of isolation } \\
\text { Keeping mind busy }\end{array}$ \\
\hline
\end{tabular}




\section{Educational Contributions}

As can be seen in Table 1, the first category was the educational contributions of the sessions. The online sessions were considered as opportunities helping the participants "further develop their communicative skills without having a break to their speaking development" (ON-4). Pointing at the communicative chances available in the online sessions, a participant offered the below remark:

"I believe I better developed my speaking abilities with the help of online sessions because I enjoyed participating in this different platform. In addition, the online sessions were really contributory because otherwise we would just have asynchronous sessions in which there was no chance to practice speaking as in the other courses." (S7-OE)

Considering the fun part in online classes, another participant explained that as they were enjoying the new online experience, they were more eager to participate in discussions and this case contributed to their speaking development:

"Compared to face-to-face classes and other asynchronous classes, the online sessions were a new experience for us and I believe we liked actively joining these sessions. Our voluntary participation was the motive developing our speaking competence." (S11-OE)

Other participants sharing a similar perspective noted that online sessions offered "a virtual setting for developing communicative skills" (S12-N3), were enjoyable because they were having "speaking practice in a different learning environment" (S23-N4), were "compensatory sessions for speaking development which is not available in other courses" (S15-3). The participants also commented that online sessions provided "chances for two-way interaction between instructor and student" (S19-3), enabled them "not to lose motivation in speaking" (S8-4) and increased their "motivation to participate in online discussion which helped the further development of speaking skills" (S21-4).

The instructor's unstructured online observation notes also highlighted the positive contributions of online sessions to the participants' willingness and motivation to engage in discussion practices $(\mathrm{ON}-2 / 3 / 5)$. The researcher observed that the online sessions increased most of the students' willingness to actively participate in online sessions and contribute to on-going discussions by sharing their perspectives. Four participants were observed to be more motivated in online discussions compared to their participation in face-to-face discussions held at the beginning of the term.

The second item in the educational contributions category was developing field-specific knowledge. As TEYL II course was based on discussions related to theoretical and practical aspects of teaching English to young learner profiles as well as the revision of approaches and methods adjusted to young learner, the course was designed to overview basic field-specific knowledge in language education. The participants appreciated the discussions in the online session which would not be held effectively only with asynchronous sessions through CMS, as reflected in the below comment: 
"If we had not had these online sessions, I believe we could not understand and learn many topics effectively as I have experienced some difficulties in understanding some theoretical issues in asynchronous courses. So, I really appreciated the online sessions as they helped us better develop our subject-matter knowledge." (S13-OE)

Another participant also highlighted the contribution of online sessions to the development of her field-specific knowledge attracting attention to the focus in online classes on the discussion compared to the case in real classroom:

"In face-to-face classes, there are several things distracting our attention and blocking our focus in-class discussions. I realized I could better concentrate on discussions during online sessions as there was only the computer and me. And, I believe this particular attention really helped me develop my field-specific knowledge.” (S20-OE)

The notes taken by the instructor and students also underlined the development of field-specific knowledge $(\mathrm{ON}-3 / 4 / 5)$. The participants were observed to "pay visible attention to the theoretical issues discussed during online sessions (ON-4) and "participate more actively in online sessions by making preliminary preparation about the week's discussion (ON-5). The participants also marked down that the online sessions were "great opportunities to revise and consolidate certain theoretical issues (S11-3) and provided "a new learning atmosphere attracting further attention to the importance of theoretical and practical knowledge" (S17-4).

\section{Pedagogical Contributions}

As displayed in Table 1, the second category was about the pedagogical contributions of online sessions. Within this category, the results underlined the increased awareness of the participants regarding different ways of conducting classes. The first item attracting attention in this category was the issue of course delivery. Since they had to make a mandatory shift from face-to-face to online sessions, the students expressed the realization that knowing different ways to conduct classes held great significance for effective teaching, as reflected in the below comment:

"Before this Corona case, I used to believe that teaching was a practice for us to be totally conducted in real classroom settings. However, experiencing this outbreak, I realized that a teacher should also be capable of teaching in different settings and online platform is one of them." (S6-OE)

The importance of developing the knowledge and capability to conduct classes in different settings was also emphasized in the following excerpt:

"This Corona experience made me realize that I need to develop my capabilities to teach in different conditions as a prospective teacher. As we are living in a constantly changing world, I may also experience such a case in my professional life." (S22-OE) 
Similar emphasis was also available in the notes regarding course delivery. The participants were observed to make comments about the effectiveness of online sessions and how this practice made them realize the significance of knowing how to conduct online classes $(\mathrm{ON}-2 / 4 / 5)$. These sessions were of great pedagogical contribution since the participants became more aware of "developing pedagogical competence in order to conduct efficient learning opportunities" (S9-4). The students who would be teachers of future underlined that this experience gave them the chance to put themselves "into the shoes of the instructor and realize how online teaching can be conducted" (S14-3) and they realized "the necessity to develop teaching knowledge and capabilities to deal with challenging situations like this" (S22-4).

The second item in the pedagogical contributions category was about virtual practice. Comparing this experience with previous face-to-face sessions, a participant expressed her views with the below words:

"We are all used to having face-to-face classes. But, this online experience is a new experience for most of us. It offered us a novel virtual practice before we graduate." (S19-OE)

Besides referring to the motivation promoted with online sessions, another participant highlighted the contribution to their pedagogical knowledge related to the control of alternative teaching settings:

"This online practice gave us the chance to have a virtual educational experience. I believe we are lucky to participate in virtual sessions because when we become teachers, we may also use such online practices." (S7-OE)

The pedagogical contributions of the online sessions were also mentioned in the observation and participant notes. The "increased awareness of knowing different ways of course delivery" (S5-4), the "realization of the importance of having the knowledge to conduct classes in different contexts (S16-3) and the "virtual practice adding more to pedagogical knowledge" (S20-4) were among the points noted by the students. The instructor notes also pointed at similar aspects of pedagogical development made possible through online sessions $(\mathrm{ON}-3 / 4 / 5)$. Some of the participants were observed to "engage themselves more actively in the virtual sessions compared to the face-to-face classes" (ON-4) and to ask "questions related to the conduct of online classes" $(\mathrm{ON} 3 / 5)$.

\section{Affective Contributions}

The third category, as shown in Table 1, was the affective contributions of online sessions. The first item frequently encountered in the participant comments was the challenge of overcoming the sense of isolation. The students stated that they were mostly staying at home because of the outbreak of the virus and had limited face-to-face interaction with their friends and other people; therefore, felt themselves isolated from the community. Participating in weekly-held sessions had an energizing 
effect on the students as they were communicating with their classmates in addition to learning new knowledge, as stated in the below comment:

"The online sessions were really a great opportunity for us because I felt really depressed and lonely, like most of my friends, because of not having real communication with anybody. With the help of this practice, we kept on learning the necessary knowledge and developing our communicative skills and we could overcome the sense of isolation by interacting with our classmates and instructor." (S18-OE)

Dealing with the feeling of isolation with the help of the classes was also stressed by another participant as follows:

"This period has been highly challenging emotionally. Evaluating the online sessions, I can say regular participation in online sessions each week kept me motivated because I had the chance to communicate with my friends and became happy to learn that they and their families were healthy. Interacting with them and our instructor gave me the sense that I was not the only one going through this hard process and this experience saved me from the sense of isolation." (S4$\mathrm{OE})$

The contributions of the sessions in helping to overcome the sense of isolation were also reflected in the participant notes. Some of the participants reflected their appreciation in terms of the affective contributions stating that the sessions created "a great chance to meet with friends and hear about them which was not possible in asynchronous classes" (S1-2), helped them "get away from the feeling of isolation" (S17-4) and offered them a platform to "communicate with classmates and overcome the sense of isolation" (S4-3). The instructor also observed that the students were talking and writing to each other asking how they were doing and how they were spending their days at the beginning and end of each session. Most of the students expressed their gratitude to the technological developments that enabled them to go on their education and interaction with their classmates and instructors.

The second item in the affective contributions category was keeping mind busy. As they were going through a mentally tiring period reading and hearing the depressing news, the students developed positive considerations of online sessions that prevented them from continuously watching the pandemic news on TV channels and gave them the feeling that life was going on. Sharing her initial concern about the online sessions at the beginning, a participant expressed that she began to enjoy this practice because it distracted her constant attention from the bad news:

"When I heard that we would have online classes each week, I was a bit unsure about its practicality. But, even after the first session, I realized that it was a really good chance for us to keep up with the course content effectively and get away from the depressive mood at least 
during online class hours. So, I should say that besides its contribution to our knowledge, these sessions helped us maintain our good mood." (S10-OE)

Holding a similar viewpoint, another participant called attention to the cheerless times he found himself in during the pandemic period enclosed at home and stressed the affective contribution of the sessions in keeping him motivated:

"In this period, I mostly found myself looking at TV for latest news about the outbreak and it was seriously disappointing. However, participating in online sessions became a motivating factor for me because I let the negative ideas go out of my mind during those hours. So, it was not just something educational; instead, it helped us recover our morale." (S14-OE)

The participant notes also supported the positive contributions of the online practice in helping the participants keep themselves away from the depressing news and situations for a certain period. The sessions enabled the students to "concentrate on the course almost forgetting about the damaging case outside" (S10-4), to "maintain positive moods by engaging in educational practices" (S18-3) and to "experience a fresh atmosphere of learning and interaction away from the depressive atmosphere" (S3-2).

\section{The Drawbacks in online sessions}

The data also pointed at several problems experienced in online sessions. As shown in Table 2, the points considered as drawbacks were the connection problems related with the quality of the internet and the interactional confusion regarding turn-taking.

\section{Table 2}

\begin{tabular}{ll}
\hline Theme 2: Drawbacks in online sessions & \\
Category 1: Connection problems & Internet consumption \\
Category 2: Interactional problems & Confusion in turn-taking \\
\hline
\end{tabular}

\section{Connection Problems}

The first category was about the connection problems to online sessions. The maim problem experienced in online session was its reliance on the Internet. Generally staying at home during the outbreak, most of the students explained that they were using their internet very much to spend their time. As participation in online sessions and watching the uploaded videos to the CMS required certain internet quota, some of the students considered this as a problem in having online sessions, as reflected in the below comment:

"If you want to participate in online sessions and to watch the videos later, you need to have a certain internet quota. As I watch a lot of movies during this period, this case sometimes created problems for me." (S12-OE) 
The students' references to the internet usage during and after the online sessions for educational purposes were also available in the instructor notes. During their mini conversations, some participants were observed to complain about possible internet consumption in online sessions (ON3/5). Especially those students who temporarily moved to villages during the pandemic were "curious about the availability of the internet (S7-4) and they expressed their concern to "have sufficient internet quota to participate in online sessions each week" (S21-3).

\section{Interactional Problems}

The second category related to the drawbacks was the interactional problems experienced in the first online session. As it was the first time for the instructor and the students to use an online program for educational purposes, the turn-taking practice during online discussions was perceived a bit confusing, as reflected in the following remark:

"It was the first time all of us to participate in discussions in online sessions. So, in the first session, I was confused about turn-taking while trying to understand who was speaking and who was going to speak next. But after this session, this issue was all resolved." (S17-OE)

The confusion with turn-taking was also reflected in the instructor and participant notes. A participant noted that it was not clear for her "who was making a comment" (S9-1). Another student wrote "I wanted to talk but since it was not clear who was talking, I hesitated to participate" (S23-2). The students were also observed to experience turn-taking problems in the first session (ON-1). As it was a new experience for them, they were having hesitations and pauses. But after the first session, they all got used to the program and started to actively participate (ON- 2/3/5).

The overall evaluation of the results indicated that the online sessions held because of the Corona pandemic received mostly positive considerations by the students. The sessions were appreciated because of the educational contributions to the students' communicative competence and field-specific knowledge; pedagogical contributions regarding course delivery and virtual practice; and affective contributions to the students' morale levels by keeping their minds occupied during the depressive period and saving them from the feeling of isolation. The online practice received few negative considerations because of minor connection and interaction problems.

\section{DISCUSSION}

The results of this intrinsic case study showed that the online sessions held during the Corona outbreak in an undergraduate course mainly received positive evaluations by the participants as regards the three-dimensional contributions despite minor drawbacks in the process. The below word cloud reflecting the notes and comments of the instructor and participants and displaying the commonly mentioned items can be enlightening to reflect a summary of the findings. 


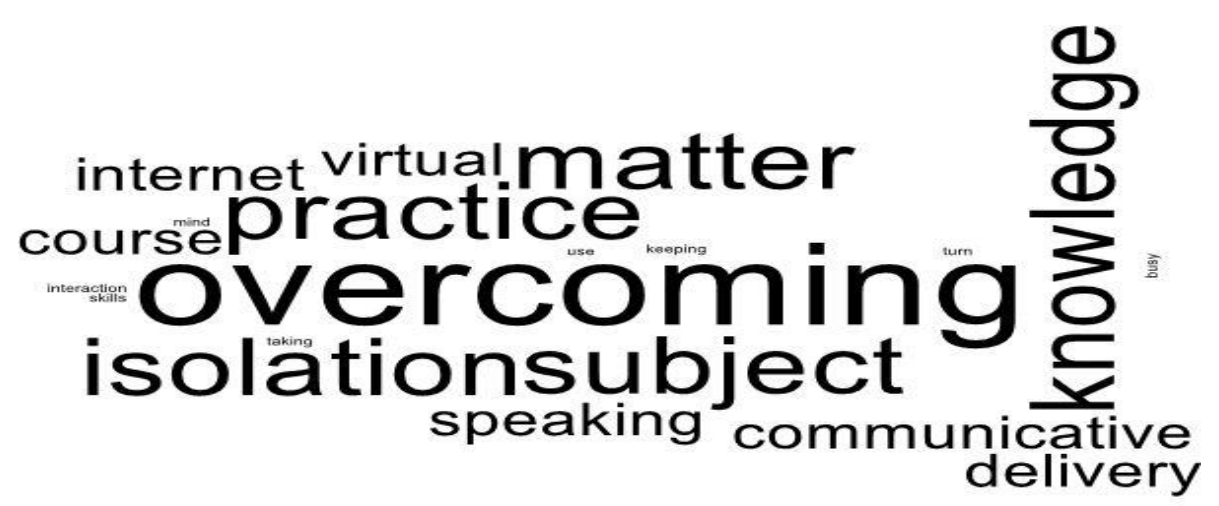

In the light of the theoretical framework, the results of this study can be discussed under three dimensions. The first dimension is related to the cognitive presence suggested in CoI framework (Garrison, 2007; Garrison, et al., 2000, 2001). The participants stated, and were observed, to take active part in the online discussions indicating their cognitive presence in the process. In order to participate in the online discussions, they studied the course content and took part in discussions. This active and voluntary participation was promoted with the cognitive presence of the participants. When this cognitive presence is analyzed in detail, it can be concluded that their cognitive activeness and presence contributed to the participants' development in communicative skills and field-specific knowledge. Since the participants were following their language education in an EFL context, classroom was the ideal context in which they could practice the language during undergraduate courses, as also stated in previous research (Nazara, 2011; Takkaç Tulgar, 2019). Because of the outbreak resulting in the cessation of courses at all educational levels, students had no chance to practice as in face-to-face education sessions. As any long-time break in communicative practices would cause gradual regression in the speaking development of ELT learners (Boonkit, 2010), the online practices provided opportunities for them to continue interactional practices through discussion sessions. In addition, the sessions kept the participants cognitively active since they were developing their field-specific knowledge with the help of the discussions. Therefore, evaluated from the perspective of cognitive presence, online sessions yielded educational contributions, promoting the students' cognitive presence, as also reflected in related research (Yang, et al., 2016).

The second dimension for discussion is related to the teaching presence proposed in CoI. The participants stated that online sessions provided them with an alternative platform to keep on revising and learning different topics through discussions. The course content which was prepared to be covered in face-to-face sessions was adapted to online sessions due to the changing situation, meeting the teaching presence criterion in CoI. The comprehensive analysis of this adapted teaching case attracts attention to the contributions of online sessions in creating awareness regarding course delivery. As prospective language teachers, the participants noted their increased awareness of the alternative ways of teaching their classes. In addition, they participated in a lively case of how to conduct a virtual course. Therefore, regarded from the teaching presence perspective, this online 
practice offered not only a provision of teaching content but also a real example of virtual lesson conduct, developing the participants' pedagogical knowledge. This practice can also be thought to contribute to the students' technological efficacy essential for successful participation in online courses (Lyons, Reysen, \& Pierce, 2012).

The third dimension for discussion has to do with the social presence proposed in CoI. Within this dimension, teaching settings are required to activate student involvement as social members. The online sessions were intended to meet this criterion since the participants contributed to the sessions with their voluntary and active participation as individuals sharing their unique perspectives in discussions, a point also underlined in previous research (Camus, Hurt, Larson, \& Prevost, 2016; Sansone, Ligorio, \& Buglass, 2018). An in-depth analysis of the sessions from the social presence perspective demonstrates that the online practice helped the participants save themselves from the feeling of isolation. Since the outbreak of the virus, participants in this study, like most of the world citizens, have been warned to stay indoors, minimizing their connections with the outside world. This limited face-to-face interaction caused feelings of loneliness and isolation for the participants who had attended real classes and spent time with their classmates in the first month of the term. However, the sense of isolation from the community was compensated with the sense of participation in a novel learning community and with the interactional chances between the instructor and students, ensuring social presence even in a virtual atmosphere. In this sense, this result is in line with the findings of Andersen (2009), Cho and Tobias (2016), Hew and Cheung (2013) and Sher (2009) while contradicting with Vonderwell's (2003). In addition, the sessions were assessed to be of affective contribution because the students had the chance to keep themselves away from the demoralizing news horrifying world citizens. The online practice can be said to have created a virtual environment for the participants to experience a virtual sense of a healthy world in which they were meeting for an educational purpose relieving themselves of mental exhaustion and refreshing their minds by joining discussions and interacting with their classmates. As a result, these sessions can be appreciated because they promoted human-to-human interaction via a virtual practice going beyond single humancomputer interaction.

Evaluated from the Sociocultural Theory (Vygotsky, 1978), the results underline the formation and maintenance of a unique learning atmosphere in which the instructor and students were engaging themselves in educational practices while they were also involved in social interactions. Meeting the demands of Sociocultural Theory, the virtual educational and social environment supported through the online sessions were appreciated by the participants as they had the chance to reflect their individual presence on the one hand, and participated in and contributed to the learning community on the other.

Though the online practice was successful at meeting the requirements of $\mathrm{CoI}$, it also received criticism because of its dependence on the Internet and the confusion experienced in the initial stages. 
Some of the students experienced problems with their internet quota, which can be considered as a natural consequence in the adoption of online sessions. The issue of turn-taking was also considered confusing particularly in the first session. However, the confusion was solved as the users got used to the integration of technology in education. It can be concluded from the drawbacks reported by the participants that undergraduate students were not as accustomed to participating in online educational settings as they were traditionally used to participating in face-to-face educational settings.

\section{CONCLUSION AND SUGGESTIONS}

This intrinsic case study focused on the effects of online sessions conducted during the Covid19 outbreak in Turkey. The participation of the voluntary students in the online sessions showed that this practice had educational contributions to students' development of their communicative skills and subject-matter knowledge. In addition, it brought pedagogical contributions increasing the participants' awareness of alternative forms of course delivery and virtual practice and affective contributions helping the participants overcome the sense of isolation and keep their minds occupied. The use of the Internet and initial confusion for turn-taking were the only reported problems.

In the light of this study, several pedagogical suggestions can be made.

- Most undergraduate courses are conducted in the face-to-face format in many higher education institutions in Turkey and possibly all around the world. It can be suggested that under/graduate courses may be partly offered through online sessions so that students and instructors can have practice through active participation. In this way, students can develop an understanding of how to conduct and manage online courses when they graduate.

- Under/graduate students can be encouraged and guided to prepare and submit online presentations and projects to develop their knowledge and capabilities in using online systems.

- In order to actualize these suggestions, the digital infrastructures should be developed to provide the essential systems for distance education to all departments.

In the light of the results of this study, future research can be suggested to involve higher number of participants and to adopt mixed methodology in order to reach more comprehensive considerations of learners' experiences and perceptions in online classes. In addition, examination of faculty members' teaching experiences in distance education during this particularly challenging period will be of great contribution to the field.

\section{REFERENCES}

Abuseileek, A. F. (2009). The effect of using an online-based course on the learning of grammar inductively and deductively. ReCALL, 21(3), 319-336. doi:10.1017/S095834400999005X 
Andresen, M. A. (2009). Asynchronous discussion forums: Success factors, outcomes, assessments, and limitations. Educational Technology \& Society, 12(1), 249-257.

Bettinger, E., Fox, L., Loeb. S., \& Taylor, E. (2017). Virtual classrooms: How online college courses affect student success. American Economic Review, 107(9), 2855-2875. https://doi.org/10.1257/aer.20151193

Boonkit, K. (2010). Enhancing the development of speaking skills for non-native speakers of English. $\begin{array}{llll}\text { Procedia-Social and } & \text { Behavioral } & \text { Sciences, } & \text { 1305-1309. }\end{array}$ https://doi.org/10.1016/j.sbspro.2010.03.191

Bosshardt, W. \& Chiang, E. (2018). Evaluating the effect of online principles courses on long-term outcomes. International Review of Economics Education, 28, 1-10. https://doi.org/10.1016/j.iree.2018.03.001

Camus, M. Hurt, N., Larson, L., \& Prevost, L. (2016). Facebook as an online teaching tool: Effects on student participation, learning, and overall course performance. College Teaching, 64(2), 84-94. DOI: 10.1080/87567555.2015.1099093

Dobbs, R., Waid-Lindberg, C., \& Carmen, A. (2017). Students' perceptions of online courses: The effect of online course experience. The Quarterly Review of Distance Education, 18(1), 93-109.

Duncan, K., Kenworthy, A., \& McNamara, R. (2012). The effect of synchronous and asynchronous participation on students' performance in online accounting courses. Accounting Education, 21(4), 431-449. DOI: $10.1080 / 09639284.2012 .67338$

Fischer, C., Zu, D., Rodrigues, F., Denaro, K., \& Warschauer, M. (2020). Effects of course modality in summer session: Enrollment patterns and student performance in face-to-face and online classes. The Internet and Higher Education, 45. https://doi.org/10.1016/j.iheduc.2019.100710

Garrison, D. R. (2007). Online community of inquiry review: Social, cognitive, and teaching presence issues. Journal of Asynchronous Learning Networks, 11(1), 61-72.

Garrison, D. R. (2009). Communities of inquiry in online learning. In P. L. Rogers, G. A. Berg,J. V. Boettcher, C. Howard, L. Justice, \& K. D. Schenk (Eds.), Encyclopedia of distance learning (2nd ed., pp. 352-355). Hershey, PA: IGI Global.

Garrison, D. R., Anderson, T., \& Archer,W. (2000). Critical inquiry in a text-based environment: Computer conferencing in higher education. The Internet and Higher Education, 2(2), 87-105.

Garrison, D. R., Anderson, T., \& Archer, W. (2001). Critical thinking, cognitive presence, and computer conferencing in distance education. American Journal of Distance Education, 15(1), 7-23.

Garrison, D. R., \& Arbaugh, J. B. (2007). Researching the community of inquiry framework: Review, issues, and future directions. Internet and Higher Education, 10, 157-172. doi:10.1016/j.iheduc.2007.04.001

Harmon, O. \& Tomolonis, P. (2019). The effects of using Facebook as a discussion forum in an online principles of economics course: Results of a randomized controlled trial. International Review of Economics Education, 30. https://doi.org/10.1016/j.iree.2019.100157

Hew, K. F., \& Cheung, W. S. (2013). Audio-based versus text-based asynchronous online discussion: Two case studies. Instructional Sciences, 41, 365-380. doi: 10.1007/s11251-012-9232-7 
Huh, S., Jin, J., Lee, K., \& Yoo, S. (2009). Differential effects of student characteristics on performance: online vis-a-vis offline accounting courses. Academy of Educational Leadership Journal, 13(2), 8391.

Kurucay, M. \& Inan, F. (2017). Examining the effects of learner-learner interactions on satisfaction and learning in an online undergraduate course. Computers \& Education, 115, 20-37. http://dx.doi.org/10.1016/j.compedu.2017.06.010

Lyons, A., Reysen, S., \& Pierce, L. (2012). Video lecture format, student technological efficacy, and social presence in online courses. Computers in Human Behavior, 28, 181-186. doi:10.1016/j.chb.2011.08.025

Moore, J. (2014). Effects of online interaction and instructor presence on students' satisfaction and success with online undergraduate Public Relations Courses. Journalism \& Mass Communication Educator, 69(3), 271-288. DOI: $10.1177 / 1077695814536398$

Nazara, A. (2011). Students' perception of EFL speaking skill development. Journal of English Teaching, I(1), 28-43. https://doi.org/10.33541/jet.v1i1.50

Nistor, N. (2013). Stability of attitudes and participation in online university courses: Gender and location effects. Computers \& Education, 68, 284-292. http://dx.doi.org/10.1016/j.compedu.2013.05.016

Ozawa, S. (2019). Effects of Japanese university students' characteristics on the use of an online English course and TOEIC scores. CALICO Journal, 36(3), 225-239. https://doi.org/10.1558/cj.36748

Palmer, S., Holt, D., \& Bray, S. (2008). Does the discussion help? The impact of a formally assessed online discussion on final student results. British Journal of Educational Technology, 39(5), 847-858. doi:10.1111/j.1467-8535.2007.00780.x

Sansone, N., Ligorio, M. B., \& Buglass, S. L. (2018). Peer e-tutoring: Effects on students' participation and interaction style in online courses. Innovations in Education and Teaching International, 55(1), 1322. DOI: $10.1080 / 14703297.2016 .1190296$

Sendag, S. \& Odabas1, F. (2009). Effects of an online problem based learning course on content knowledge acquisition and critical thinking skills. Computers \& Education, 53, 132-141. doi:10.1016/j.compedu.2009.01.008

Sher, A. (2009). Assessing the relationship of student-instructor and student-student interaction to student learning and satisfaction in web-based online learning environment. Journal of Interactive Online Learning, 8(2), 102-120.

Stake, R. E. (1995). The art of case study research. Thousand Oaks, CA: Sage.

Takkaç Tulgar, A. (2019). A tale of two contexts: Attitudes of learners towards listening in foreign context and target context. International Journal of Listening. https://doi.org/10.1080/10904018.2019.1604139

Vonderwell, S. (2003). An examination of asynchronous communication experiences and perspectives of students in an online course: A case study. Internet \& Higher Education, 6(1), 77-90. http://dx.doi.org/10.1016/S1096-7516(02)00164-1.

Vygotsky, L. (1978). Mind in society: The development of higher psychological processes. London, UK: Harvard University Press.

Wei, H., Peng, H., \& Chou, C. (2015). Can more interactivity improve learning achievement in an online course? Effects of college students' perception and actual use of a course-management system on 
their learning achievement. Computers \& Education, 85, 10-21. http://dx.doi.org/10.1016/j.compedu.2014.12.013

Xu, D. \& Jaggars, S. S. (2013). The impact of online learning on students' course outcomes: Evidence from a large community and technical college system. Economics of Education Review, 37, 46-57. http://dx.doi.org/10.1016/j.econedurev.2013.08.001

Yang, J., Quadir, B., Chen, N., \& Miao, Q. (2016). Effects of online presence on learning performance in a blog-based online course. The Internet and Higher Education, 30, 11-20. http://dx.doi.org/10.1016/j.iheduc.2016.04.002

Zhan, Z., Xu, F., \& Ye, H. (2011). Effects of an online learning community on active and reflective learners' learning performance and attitudes in a face-to-face undergraduate course. Computers \& Education, 56, 961-968. doi:10.1016/j.compedu.2010.11.012

Zhang, X. (2016). An analysis of online students' behaviors on course sites and the effect on learning performance. Journal of Education for Library and Information Science, 57(4), 255-270. 